\title{
Çalışanların Yaşam Tatmini ve Öz Yeterlilik Algısının Girişimcilik Eğilimlerine Etkisi
}

\author{
Edip ÖRÜCÜ ${ }^{1}$ ve Itır HASIRCI ${ }^{2}$
}

\section{Öz}

$\mathrm{Bu}$ araştırmanın amacı çalışanların girişimcilik eğilimlerinin üzerinde yaşam tatminlerinin ve öz yeterlilik algılarının etkisini belirlemektir. Araştırmanın evrenini Bandırma da bulunan bir kamu iktisadi teşebbüsünde çalışan 650 işgören oluşturmakta olup, örneklemini ise 470 işgören oluşturmaktadır. Elde edilen verilerle güvenilirlik analizi, frekans analizi, normallik testi, çoklu regresyon analizi yapılmıştır. Yapılan regresyon analizi sonucunda öz yeterlilik algısının girişimcilik eğilimleri üzerinde pozitif yönlü ve anlamlı bir etkisinin olduğu görülmüştür. Ayrıca yaşam tatmininin girişimcilik eğilimleri üzerinde negatif yönlü ve anlamlı bir etkisinin olduğu tespit edilmiştir. Çalışmanın sonuçları itibariyle girişimcilik eğilimlerinin geliştirilmesi açısından çalışanların öz yeterlilik algılarının yükseltilmesine dönük faaliyetlerin yararlı olacağı anlaşılmıştır.

\section{Anahtar Kelimeler: Girişimcilik Eğilimleri, Öz Yeterlilik Algısı, Yaşam Tatmini, İşgören}

\section{The Effect of Employees' Life Satisfaction and Self Efficacy Perceptions on Entrepreneurial Tendency}

\section{Abstract}

The aim of this study is to determine the effect of life satisfaction and self-efficacy variables on employee entrepreneurial tendencies. 650 employees working in a state-owned enterprise located in Bandirma make up the universe of the study, and 470 employees make up the sample. Reliability analysis, frequency analysis, normality test, correlation analysis, multiple regression analysis were performed with the data obtained. As a result of regression analysis, self-efficacy has a positive and significant effect on entrepreneurial tendencies. In addition, life satisfaction has been found to have a negative and significant effect on entrepreneurial tendencies. As a result of study, it has been understood that activities aimed at increasing the self-efficacy perceptions of employees will be beneficial in terms of developing entrepreneurial tendencies.

Key Words: Entrepreneurship Tendencies, Self-efficacy Effect, Life Satisfaction, Employee

\section{Atıf İçin / Please Cite As:}

Örücü, E. ve Hasırcı, I. (2022). Çalışanların yaşam tatmini ve öz yeterlilik algısının girişimcilik eğilimlerine etkisi. Manas Sosyal Araștrrmalar Dergisi, 11(1), 246-258.

\footnotetext{
1 Prof. Dr. - Bandırma Onyedi Eylül Üniversitesi İktisadi ve İdari Bilimler Fakültesi, eorucu@bandirma.edu.tr

(iD) ORCID: 0000-0002-3301-7496

2 Doktora Öğrencisi - Bandırma Onyedi Eylül Üniversitesi Sosyal Bilimler Enstitüsü, itir8686@gmail.com

(iD) ORCID: 0000-0002-5449-2640
} 


\section{Giriş}

Kamu iktisadi teşebbüslerinde girişimcilik eğilimlerinin artırmasına duyulan ihtiyaç bu çalışmanın önemini belirtmektedir. Yaşam tatmini, öz yeterlilik algısı ve girişimcilik eğilimleri değiş̧kenleri arasındaki ilişkiyi ele alan herhangi bir araştırmanın olup olmadığını tespit etmek amacıyla yerli ve yabancı literatür incelenmiş ancak üç değişkenin bir arada olduğu çok sayıda çalışmaya rastlanmamıştır. Bu çalışmanın öz yeterlilik algısı, yaşam tatmini ve girişimcilik eğilimleri arasındaki ilişkiyi ele alan nadir çalışmalardan biri olması edeniyle literatüre katkılar sağlayacağı umulmaktadır. Bu araştırmanın amacı çalışanların girişimcilik eğilimleri üzerindeki yaşam tatmini ve öz yeterlilik algııı değiş̧kenlerinin etkisini belirlemektir.

Çalışanların girişimcilik eğilimlerinin nasıl arttırılabileceği sorusu bu araştırmanın temel problemini oluşturmaktadır. Bu bağlamda girişimcilik eğilimi üzerinde etkisi olduğu önceki çalışmalarda da vurgulanan öz yeterlilik algısı ve çalışanların yaşam tatmini değisskenleri bağımsız değissken olarak ele alınmış, girişimcilik eğilimleri üzerindeki etkileri araştırılmışır.

\section{Kavramsal Çerçeve}

\section{Girişimcilik Eğilimi}

Girişimcilik eğilimi, doğuştan kazanılmış bir davranış olsa da ortaya çıkartılması, geliştirilmesi ve yönlendirilmesi gereklidir (Ersoy, 2010, s. 73). Girişimcilik eğiliminin oluşmasında etkili olan faktörler aşağıdaki şekilde sıralanabilir (Güreşçi, 2014, s. 24):

- Bireyin özellikleri.

- Bölgesel ve çevresel etmenler.

- Eğitim düzeyi.

- Ekonomi ve siyaset.

Bu faktörler bireyde girişimcilik eğilimini ortaya çıartan ve geliştiren faktörlerdir. Ve bu faktörlerin hepsi birbirini tamamlayan yapıdadır. Bu faktörlerden eğitim yoluyla bireyde girişimciliğin geliştirilmesi ülkemiz gerçekleri ile yakından ilgilidir (Demir, Yıldız ve Fırat, 2020, s. 27). Eğitimli ve girişimcilik eğilimi olan bireyler sayesinde ülkemizin kaynakları daha verimli kullanılabilir.

Girişimcilik eğiliminin bireylerde oluşumunda, aile, eğitim, kişisel değerler gibi faktörler etkili olmaktadır. Bu faktörlere, girişimcilik yeteneği, girişimcilik eğitimi, genel eğitim seviyesi, ekonomik, siyasi faktörler ve doğal faktörler de eklenebilir (İşcan ve Kaygın, 2011, s. 280). Girişimcilik eğilimi olan bireyler hayata atılmak, tutunmak isterler ve enerjik yapıları ile iş firsatlarını rahatlıkla işe çevirebilirler (Morris, Vuuren, Cornwall ve Scheepers, 2009, s. 431).

Girişimcilik eğilimi olan bireyleri kendi işlerini kurmaya iten birçok unsur vardır (Tajeddini, 2010, s. 222). Bunlar; kazanç sağlama isteği, hayallerini gerçekleştirme isteği, işsizlik, mevcut işinde kendini kalıcı hissetmeme düşüncesi, bağımsız iş yürütme isteği, yüksek özgüvene sahip olmak vb. şeklinde sıralanabilir. Bu faktörlerin hepsi bireylerin girişimciliğe başlamaları için ön koşullarıdır (Güreşçi, 2014, s. 24).

Girişimcilik eğilimi kavramı bireysel ve çevresel faktörlerin bir araya geldiği, kişilerin kendi işini yapma konusundaki kararlllı̆ı̆nı temsil etmektedir (Arslan, 2002, s. 2). Bu eğilimin birçok farklı sebepten sergilendiğini söylemek mümkündür. Bu sebepler; başkasına bağlı olmadan çalışma, emir almama, daha çok para kazanma, saygınlık kazanma, kendi işinin patronu olma, becerilerini kendi işi için kullanma, neler başarabileceğini görmek, çabalarına karşıllk adil bir ücret elde etmek şeklinde sıralanabilir. Girişimcilik eğiliminin üç faktörün birleşmesinden oluştuğu bilinmektedir (Shane ve Venkataraman, 2000, s. 221):

- Bireyin girişimcilik ile ilgili aldığı eğitim ve yeni riskleri üstlenme yetkinliği.

- Bireyin ekonomik firsatlara ilişkin sahip olduğu inançlar.

- Mevcut firsatları önceden görmek ve değerlendirmek noktasında kendine duyduğu özgüven.

Girişimcilik eğilimi, bireyin girişimci olma arzusu ve bu sebeple kendisine güvenmesi ile ilgilidir. Girişimcilik eğilimi kavramının sonradan $\mathrm{m}$ kazanıldığı yoksa doğuştan $\mathrm{m}$ geldiği bilinmemekle beraber doğuştan gelmiş ise bir davranış olarak ortaya çıkarılması, geliştirilip, yönlendirilmesi gerekir (Seçgin, 2020, s. 815). İç girişimcilik kavramı girişimcilik türlerinden biridir. Bir çalışanın bulunduğu organizasyonda geliştirdiği bir yenilik ile o organizasyona önemli atılımlar yaptırması durumudur. İç girişimcilik eğilimi girişimcilik eğiliminin bir uzantısı olarak görülebilir. 
Girişimcilik eğilimleri ile ilgili çalışmalar genellikle girişimcilik eğitimleri veya sosyo demografik değişkenlere göre farklılaşma üzerine yapılmıştır. Bu sebeple girişimcilik eğilimleri ile ilgili literatürdeki çalışmalar incelendiğinde aşağıdaki örnekler verilebilir:

Arslan tarafindan 2002 senesinde öğrenciler arasında yapılmış olan çalışmanın sonucuna göre gelir düzeyleri ile girişimcilik eğilimleri arasında olumlu ilişkiler bulunmuştur (Arslan, 2002, s. 6). Bockorny ve Morgan tarafindan 2019 yılında 152 girişimciye yapılan çalışmada girişimcilerin cesareti, yaşam tatmini ve psikolojik sermayesinin korelasyonunun anlamlı olduğu görülmüştür (Bockorny ve Morgan, 2019, s. 4).

\section{Öz Yeterlilik Algısı}

Bandura'nın (1997) öz yeterlilik algısı kavramı, bireyin zorluklarla karşılaşsa dahi belli bir performansı gerçekleştirmek için asla pes etmemesi anlamına gelmektedir (Tuncer ve Tanaş, 2011, s. 227). Öz yeterlilik algisı yüksek olan çalışan, görevini ifa ederken dışarıdan destek görmeye asla gerek duymadan o işi içinden geldiği gibi yapar. Belirtilenlerden yola çıkarak bir bireyde öz yeterlilik inancı ne kadar yüksekse, çaba, 1srar ve devamlilığın o oranda artacağı söylenebilir. Öz yeterlilik inançları az olan bireyler ise, olayların göründüğünden daha güç olduğu düşüncesindedirler ve olaylara sı̆̆ bakış açısı ile baktıklarından sorunlarını çözüme kavuşturamazlar. Öz yeterlilik algısı, çalışanların motivasyon ve davranışlarının mühim bir parçasını oluşturmakla kalmaz, yaşamlarını değiştirebilecek faaliyetleri de etkiler. Öz yeterlilik algısının amacı, kişilerin kendilerini yeterli hissettikleri faaliyetleri gerçekleştirme olasılıklarının fazla; yeterli olmadıklarını düşündükleri faaliyetleri gerçekleştirme olasılıklarının ise nispeten az olduğu yönündedir (Arseven, 2016, s. 71).

Bandura'ya göre öz yeterlilik alg1sı, kişilerin hedeflerine ulaşmak için bir dizi eylem planı organize etmeleri ve bu eylemleri yerine getirme çabalarıdır (Aşkar ve Umay, 2001, s. 5). Bandura öz yeterliliğin farklı boyutlar itibariyle farklılaştı̆̆ını belirtmektedir. $\mathrm{Bu}$ boyutlardan birincisi düzey itibariyle farklılaşmadır. $\mathrm{Bu}$ kavram görevlerin zorluk derecesine göre öz yeterlilik algısının kişiden kişiye farklılaşabileceğini ifade etmektedir. İkinci boyut ise genelleme durumuna göre farklılaşmadır. Bu kavram da bazı deneyimlerin sınırlı bir algıya yol açtı̆̆ın, bazı deneyimlerin de belirli davranış kalıplarının ötesine geçen genelleştirilmiş bir yeterlilik duygusu aşıladığını ifade etmektedir. Bu kavram da beklentileri güçlü olan bireylerin olumsuz deneyimlere rağmen çaba sarf etmeye devam etmeleri anlamına gelmektedir (Friedman, 2003, s. 121).

Kişilerin belli bir işi yapabileceğine dair duyduğu inanc1 ortaya koyan öz yeterlilik algisı kavramı, kişilere o işi başarabilmek için gereğinden daha fazla çaba sarf etmeleri hususunda güdüleyici bir etkiye sahiptir (Kotaman, 2008, s. 125). Bu kavrama göre kişi belirli görevleri kendisinden beklenildiği şekilde yapacağına dair güven beslemektedir. Çalışanların hayat boyu edindikleri tecrübeler zor durumlarla mücadelede kendilerine yardımcı olabilecektir. Bu sebeple öz yeterlilik algısı kişilerin bireysel gelişimlerinin söz konusu olduğu her yerde rastlanılan bir olgu haline gelmiştir (Çetin, 2011, s. 85).

Yeterli derecede yetenek sahibi olup da o işi yapabileceğine dair inancı olmayan iş gören öz yeterlilik seviyesinin düşük olmasından dolayı başarıyı yakalayamamaktadır. Bunun tam tersi düşünüldüğünde öz yeterlilik algisı yüksek bir çalışan kendisinden beklenen performansın da üzerinde olumlu bir etki yaratmaya başlamaktadır (Özerkan, 2007, s. 30). Çalışanların öz yeterlilik algıları çalışıkları kurumda gerçekleştirdikleri performanslarının yanında kurum içerisinde süre gelen tüm süreçleri de etkiler. Çalışanların ortaya koyması gereken performans derecesinin en önemli etkeni öz yeterlilik kavramıdır (Sözbilir, 2011, s. 128). Kişilerin öz yeterlilik inançlarını sağlayabilmek için rol model olarak gördüklerinin performanslarını göz önüne almaları önemlidir. Bu kişiler için kendi öz yeterlilik düzeyleri ile ilgili bilgi diğer kişileri gözlemlemekten, başka bireyleri ikna edebilme kabiliyetlerinden vb. elde edilir.

Literatürde öz yeterlilik algısı ile ilgili birden fazla tanım yapılmıştır. Luszczynska, Gutierrez-Dona ve Schwarzer (2005, s. 82) öz yeterlilik algısı kavramını zor şartlarda kişinin sahip olduğu beceriyi kontrol edebilme kabiliyeti olarak tanımlamıştır. Zimmerman (2000, s. 82) kişinin hedeflediği işi tamamlaması ve sonucunda başarı elde etmesi şeklinde öz yeterlilik kavramını açıklamıştır. Oğuzhan (2020, s. 438) öz yeterlilik kavramının kolaylıkla anlaşılabilen bir kavram olmadığını, kişilerin belli koşullar altında bir işi yapmak için kendi kapasitelerine duydukları içsel inancın öz yeterlilik kavramıyla açılanabileceğini belirtmiştir.

Çalışanların belli bir performansa sahip olup, bunu gösterebilmesi hali olarak tanımlanan öz yeterlilik algısı, kişilerin ustalık ve başarı seviyelerine göre her türlü psikoterapi ve davranışsal değişimin ortak bir mekanizma ile işleyişi şeklinde ifade edilebilir (Sherer ve Maddux, 1982, s. 665). Diğer bir ifadeyle öz 
yeterlilik, gerekli kazanımların sağlanması için yeteneklerinin keşfi ve ilerletilmesi adına eğitimler düzenlenmesidir (Bong ve Skaalvik, 2003, s. 10). Öz yeterliliği yüksek olan bireylerin belli başlı özellikleri şunlardır (Bandura, 1997, s. 197):

- Hedefleri yüksektir.

- Karşılaştıkları zor durumlar karşısında mücadele ederler.

- Bakış açıları oldukça geniştir.

- Başarısızlıkları sonucunda öz eleştiri yaparlar.

- Stresle savaşabilirler.

Öz yeterlilik algısı ile ilgili yerli ve yabancı literatürdeki çalısmalardan bazı örnekler aşağıda yer almaktadır:

Friedman (2003) çalıșmasında Öz yeterlilik ile tükenmișlik arasındaki ilișkiyi ortaya koymuștur. Bu amaçla, 322 İsrailli öğretmen arasında anket çalsşması düzenlenmiştir. Yapılan Manova ve regresyon analizleri neticesine bakılırsa öz yeterlilik ile tükenmişlik arasında anlamlı bir ilişki olduğu görülmüştür (Friedman, 2003, s. 201).

Yorgancı ve Bozgeyikli (2016) tarafından yapılan çalışmanın teması sınıf öğretmenlerinin öz yeterlilik algılarıly örgütsel güven algıları arasındaki ilişkinin tespit edilmesidir. Bu sebeple 2015-2016 yılları eğitim ögrretim döneminde Kayseri’de ilçelerde 15 ilköğretim okulunda görev yapmakta olan 300 öğretmen arasında bir anket çalışması gerçekleştirilmiştir. Toplanan verilerle yapılan analizler neticesinde öğretmenlerinin öz yeterlilik ile örgütsel güven seviyeleri arasında olumlu ilişkiler bulunmuştur (Yorganc1 ve Bozgeyikli, 2016, s. 52).

Nobre vd. (2019) tarafindan yapılan çalışma gelişimsel bozukluk yaşayan çocuklar ile risk altında yaşayan çocuklar arasında günlük öz yeterlilik profilini belirlemek amacıyla hazırlanmıştır. Çalışmanın evrenini 6-8 yaşlarında 140 çocuk oluşturmaktadır. Verilerin analiz sonuçlarına göre öz yeterlilik algısının grupların ayrilmasında önemli bir faktör olduğu tespit edilmiştir (Nobre, 2019, s. 8).

\section{Yaşam Tatmini}

Tatmin kavramı, arzu edilen bir düşüncenin gerçeklemesini sağlama, doygunluk olarak tanımlanmaktadır. Tatmin olmak ise bireyin arzu ettiği herhangi bir şeye ulaşıp, hoşnut olmasıdır. Belirtilen iki tanımdan yola çıkarak yaşam tatmini kavramı da bireyin kendi yaşantısını beğenmesi, memnuniyet duyması şeklinde tanımlanabilir (Haybron, 2007, s. 121). Bu durumda yaşam tatmini kişinin sadece bir durumdan değil, hayatının tamamından memnun olması anlamına gelen bir kavramdır ve sübjektif bir yapıya sahiptir. Kişinin talepleri ile yaşadığı anlık durum kıyaslandığı zaman bu kişinin hayatı ile ilgili pozitif bir alg1ya sahip olduğu görülürse, yaşam tatmininin yüksek, negatif bir algiya sahip olduğu görülürse yaşam tatmininin düşük olduğu söylenebilir (Yöney ve Kilınç, 2020, s. 41).

Yaşam tatmini kavramı ilk olarak Neugarten tarafından ortaya atılmıştır. Bu kavram bireyin günlük hayattaki aktivitelerden keyif almasını, yaşantısının anlamlı olmasını, hayata dair amaçlarının olmasını, bu amaçlara eriştiğine dair inancının tam olmasını ifade eder. Yaşam tatmini sağlanan birey, kendini değerli hisseder ve hayata daha olumlu bir bakış açısıyla yaklaşmaya başlar (Kaya, 2006, s. 3). Bireylerin yaşamdan duydukları tatmini ifade eden yaşam tatmini, duygusal temelli ve kendi yaşam kalitelerini kendilerinin değerlendirdikleri bir süreç olarak tanımlanmaktadır (Özer ve Karabulut, 2003, s. 73). Bireylerin yaşamdaki beklentilerinin gerçekleşme derecesi yükseldikçe yaşam tatminleri de yükselebilecektir. Beklentiler ile yaşamın getirdikleri arasındaki uyum sonucu oluşan pozitif duygulanıma yaşam tatmini denilmektedir. Yaşam tatmini, yaşam kalitesinin en önemli etmenlerden biri olmakla beraber bireylerin zihinsel ve fiziksel sağlıklarının ne kadar iyi gelişim gösterdiğini de açıklamaktadır (Dejonge, Veenhoven, Kalminjn ve Arends 2016, s. 881). Özer ve Karabulut (2003, s. 73) kişinin elindekilerle beklentilerinin karşılaştrrılması sonucunda elde edilen sonucun yaşam tatmini olduğunu belirtmiştir. İlgili literatür yaşam tatminini etkileyen birçok faktörün olduğunu ortaya koymaktadır. Bu faktörler;

1. Toplumsal Faktörler: Sosyal ağlar, akrabalar arası ilişkileri, üyelikler (Diener, 1985, s. 553).

2. Çevresel Faktörler: Yeni iş bulma firsatları (Donovan ve Halpern, 2002, s. 7).

3. Demografik ve Kişiye Ait Faktörler: Yaş, cinsiyet, eğitim, duygusallık (Diener, 1985, s. 553).

4. İş İle İlgili Faktörler: Kişinin çalıştığı örgütteki rolü, iş yükü, işinin niteliği, tecrübe (Bir, 2017, s. 17). 
Literatürde yaşam tatmini ile ilgili çalışmalar genellikle iş tatmini kavramı ile ilişkilendirilmiştir. Aşan ve Erenler tarafindan 2008 yllinda Ankara'daki bir devlet üniversitesinde görev yapan 70 akademisyene anket uygulaması gerçekleştirilmiştir. Yaşam tatmini ve iş tatmini arasındaki ilişkiyi tespit etmeye yönelik yapılan bu çalışmanın sonucunda iki değişkenin korelasyonu pozitif yönlü ve anlamlı bulunmuştur (Aşan ve Erenler, 2008, s. 208). Yaşam tatmini ve iş tatmini ilişkisini araştıran diğer çalışma 350 öğrenci ile (2010) Rice, Near ve Hunt'ın yaptı̆̆ çalışmadır. Bu araştırmanın analiz sonuçlarına göre yaşam tatmini ile iş tatmini arasındaki korelasyon çok zayıf bulunmuştur (Rice vd., 1980, s. 45).

\section{Yazın Taraması ve Hipotezler}

İlgili literatür incelendiğinde değişkenler arasındaki ilişkileri ele alan şu araştırmalara ulaşılımıştır;

\section{Öz Yeterlilik Algısı ve Girişimcilik Eğilimleri Arasındaki İlişkiyi Araştıran Çalışmalar}

Meydan (2011) Ankara'da bulunan çeşitli kamu kurumlarında görev yapan 172 yönetici ile bir anket çalışması gerçekleştirmiştir. Çalışmada yapılan analizlerin sonucuna göre iş tatmini ve öz yeterlilik algısının girişimciliği anlamlı ve pozitif yönde etkilediği belirlenmiştir (Meydan, 2011, s. 32).

Armağan ve Gürsoy tarafindan 2017 senesinde yapılan çalısmanın örneklem sayısı Aydın ilinde yaşayan 18 yaş ve üzeri 482 tüketicidir. Yapılan analizlerin neticesine göre tüketicilerin öz yeterlilik algıları ile sosyal girişimcilik eğilimleri arasında anlamlı ilişkilerin olduğu görülmüştür (Armağan ve Gürsoy, 2017, s. 555).

Prihatsanti tarafindan 2017 senesinde yapılan çalışma 116 kolej öğrencisinin girişimcilik, öz yeterlilik algıları ve yenilikçi davranışları arasındaki ilişkiyi belirlemek amacıyla yapılmıştır. Analizlerden elde edilen sonuca göre üç değişkenin birbiriyle pozitif yönlü ve anlamlı korelasyonu olduğu tespit edilmiştir (Prihatsanti, 2017, s. 131).

Özgül ve Yücel tarafindan 2018 senesinde 245 girişimci adayının girişimcilik eğilimi ile yenilikçilik davranışları arasındaki ilişkide öz yeterliliğin aracılık rolü belirlenmiştir. Yapılan analiz sonuçlarına göre yenilikçi davranış ile girişimcilik arasındaki ilişkide öz yeterliliğin kısmi aracılık etkisinin olduğu görülmüştür (Özgül ve Yücel, 2018, s. 348).

Ceyhan vd. tarafından 2020 senesinde yapılan çalışma Çukurova Üniversitesi İktisadi ve İdari Bilimler Fakültesi'nde öğrenim görmekte olan 124 üniversite öğrencisi ile gerçekleştirilmiştir. Duygusal zekâ ve girişimcilik eğilimleri arasındaki ilişkide öz yeterliliğin rolünü tespit etmek amacıyla gerçekleştirilen bu çalışmanın sonucuna göre öz yeterlilik algısının girişimcilik eğilimlerini anlamlı yönde etkilediği tespit edilmiştir (Ceyhan, Ylltay ve Batga, 2020, s. 15).

Yağar vd. tarafından 2020 senesinde gerçekleştirilen çalışmanın örneklemi 339 üniversite öğrencisidir. Üniversite öğrencilerinin öz yeterlilik düzeyleri ve demografik faktörlerinin girişimcilik eğilimleri üzerindeki etkisini belirlemeye yönelik yapılan çalısmanın sonucuna göre öğrencilerin öz yeterlilik düzeyleri ile girişimcilik eğilimleri arasında anlamlı bir ilişkinin olduğu sonucuna ulaşılmıştır (Yağar vd., 2020, s. 308).

Sosyal değişim kuramının temel prensibi karşılıklılık normudur. Sosyal değişim kuramı, bir etkileşim durumunda bireyler ve gruplar arasındaki kaynak alısverişini anlama ile ilgili genel bir sosyal bilim kuramıdır (Kulualp ve Sarı, 2019, s. 659). Yöneticilerin çalışanlarının öz yeterlilik algılarını yükseltmeye dönük çabalarının onların girişimcilik eğilimlerini etkileyeceği düşüncesi ile hareket edilmiş ve araştırmanın hipotezleri sosyal değişim kuramına göre oluşturulmuştur.

Öz yeterlilik algısının girişimcilik eğilimleri üzerindeki etkisini ele alan literatür taramasında açıkladığımız çalışmaların da ışığında aşağıdaki hipotez geliştirilmiştir:

$\mathbf{H}_{1}$ : Öz yeterlilik algısının girişimcilik eğilimleri üzerinde anlamlı bir etkisi vardır.

\section{Yaşam Tatmini ve Girişimcilik Eğilimi Arasındaki İlişkiyi Araştıran Çalışmalar}

Akgündüz tarafindan 2013 senesinde Kuşadası'nda bulunan 203 konaklama işletmesi çalışanı arasında iş doyumu, yaşam tatmini ve öz yeterlilik algısı arasındaki ilişkiyi tespit etmek amacıyla yapılmış olan çalışmanın sonucuna göre iş doyumu ve yaşam tatmini arasındaki ilişkide öz yeterlilik algısının kısmi aracılık etkisi olduğu görülmüştür (Akgündüz, 2013, s. 192).

Uçkun vd. tarafindan 2019 senesinde yapılan çalısma öz yönelimin yaşam tatmini üzerindeki etkisinde girişimcilik eğilimlerinin aracllık rolünü tespit etmeyi amaçlamıştır. Bu araştırmanın sonucuna göre öz 
yönelimin yaşam tatmini üzerindeki etkisinde girişimcilik eğilimlerinin aracllık etkisi olduğu tespit edilmiştir (Uçkun vd., 2019, s. 158).

Thomas ve Malagi (2020) tarafindan Hindistan'in Kerala eyaletinde yaşayan 60 girişimci arasında yapılan çalışmada girişimcilerin ve profesyonel çalışanların mutluluk, yaşam tatmini ve öz yeterlilik algıları arasındaki ilişkinin belirlenmesi amaçlanmışır. Yapılan analizlerin sonucuna göre yaşam tatmini öz yeterlilik algısı ve mutluluk arasındaki korelasyon anlamsız bulunmuştur (Thomas ve Malagi, 2020, s. 1106).

Gök tarafından 2020 senesinde 203 sosyal hizmet bölümü öğrenci arasında yapılan çalışma yaşam tatminin yordayan değişkenleri tespit etmeyi amaçlamıştır. Araștırma sonucunda, öz yeterliliğin yaşam tatmini üzerinde anlamlı etkisinin olduğu tespit edilmiştir (Gök, 2020, s. 869).

Yaşam tatmininin girişimcilik eğilimleri üzerindeki etkisini ele alan literatür taramasında açıkladığımız çalışmaların da ışı̆̆ında aşağıdaki hipotez geliştirilmiştir:

$\mathbf{H}_{2}$ : Yaşam tatmininin girişimcilik eğilimleri üzerinde anlamlı bir etkisi vardır.

\section{Yöntem}

\section{Araştırmanın Amacı ve Modeli}

Bu araştırmanın amacı çalışanların girişimcilik eğilimleri üzerindeki yaşam tatmini ve öz yeterlilik algısı değişkenlerinin etkisini belirlemektir. Bu amaçla aşağıdaki model geliştirilmiştir.

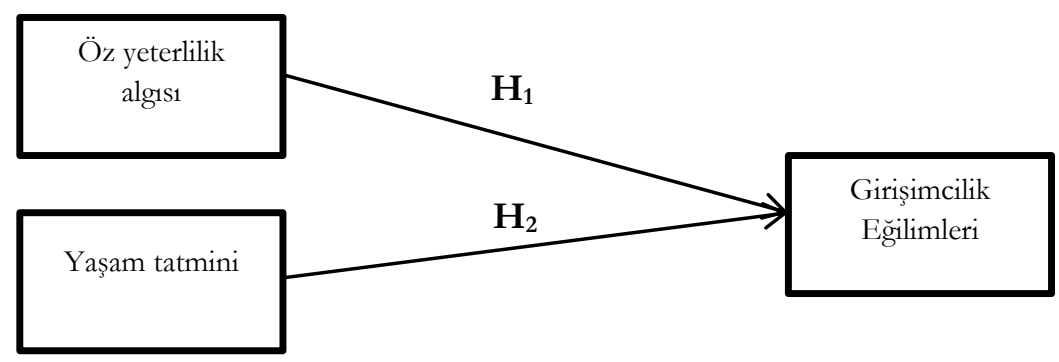

Şekil 1. Araștırmanin Modeli

\section{Evren ve Örneklem}

Araştırma için Bandırma ve Ankara'da şubeleri bulunan bir kamu iktisadi teşebbüsü tercih edilmiştir. $\mathrm{Bu}$ kuruluşta anket çalışmasını gerçekleştirmek amacıyla Bandırma Onyedi Eylül Üniversitesi etik kurulundan 2020/3 toplant1 nolu ve 18.06.2020 tarihli "Etik Kurul Onayı" alınmıştır. Araştırma 20-25 Haziran 2020 tarihleri arasında yapılmıştır. Araştırmanın evrenini Bandırma ve Ankara'da bulunan kamu iktisadi teşebbüsünde çalışmakta olan 650 işgören, örneklemini ise bu işletmede çalışan 470 işgören oluşturmaktadır. Aşağılda yapılan hesaplama sonucunda örneklemin evreni temsil yeteneği olduğu sonucuna ulaşılmıştır.

$$
n=\frac{n_{0}}{1+n_{0} / \mathrm{N}} \quad n_{0}=\frac{t^{2} x s^{2}}{d^{2}}
$$

N: Evren büyüklüğü

n: Örneklem büyüklüğü

t: Güven düzeyine karşıllk gelen tablo z değeri (0,05 için 1.96, 0.01 için 2.58 ve 0.001 için 3.28)

s: Evren için tahmin edilen standart sapma

d: Kabul edilebilir sapma tolerans1

Araştırmada güven düzeyi olarak \%95 (alfa 0,05 için z tablosu değeri $(t)=1,96$ ), standart sapma değeri ise 0,5 (s) olarak alınmıştır (Gürbüz ve Şahin, 2017, s.318).

$$
n=\frac{384,16}{1+\frac{384,16}{650}}=241,61 n_{0}=\frac{1.96^{2} \times 0.5^{2}}{0.05^{2}}=384,1
$$




\section{Veri Toplama Araçları}

Araştırmada veriler anket formu aracılı̆̆g ile toplanmıştır. Demografik sorular hariç, diğer üç ölçekte çalışanların ifadelere katılım seviyeleri, 5'li Likert Ölçeği ile belirlenmiştir (1=Kesinlikle Katılmıyorum, 5=Kesinlikle Katılıyorum). Anket formu toplam 27 sorudan oluşmaktadır. Anket formlanı yüz yüze görüşülerek birebir doldurtulmuştur. Anket formunun birinci bölümünde çalışanların öz yeterlilik algıllarını ölçmek amaciyla toplam 10 sorudan oluşan, Ralf Schwarzer, Esther Greenglass, John Muller (1999) tarafından geliştirilen "Öz Yeterlilik Ölçeği” kullanılmışır. Anket formunun ikinci bölümünde çalışanların girişimcilik eğilimlerini ölçmek amaciyla toplam 8 sorudan oluşan, Yılmaz ve Sünbül tarafindan (2009) geliştirilen "Girişimcilik Ölçeği” kullanılmışır. Anket formunun üçüncü bölümünde toplam 5 sorudan oluşan, Diener, Emmons, Larsen ve Griffin (1985) tarafindan geliştirilen "Yaşam Tatmini" ölçeği kullanılmıştır. Anket formunun dördüncü bölümünde ise katılımciların demografik bilgilerini tespit edebilmek için araştırmacı tarafından hazırlanan, 4 sorudan oluşan (cinsiyetiniz, yaşınız, eğitim, medeni durum) ifadelere yer verilmiştir.

\section{Geçerlik ve Güvenilirlik Analizleri}

Güvenilirlik, ölçüm araçlarının farklı zamanlarda, farklı yerlerde, aynı evren içinden seçilen farklı örnekleme uygulandığında, benzer sonuçlar vermesi olarak tanımlanmıştır. Bir başka ifadeyle, aynı ölçüm aracı ile farklı zamanlarda yapılan ölçüm sonuçları arasındaki tutarlılıktır. Güvenilirlik kısacası, ölçüm araçlarının ne kadar tutarlı ölçüm yaptığını ifade etmektedir (Gürbüz ve Şahin, 2017, s. 263).

Araştırmada kullanılan, 10 ifadeden oluşan öz yeterlilik ölçeği, 8 ifadeden oluşan girişimcilik eğilimleri ölçeği ve 5 ifadeden oluşan yaşam tatmini ölçeği kullanılmış olmakla birlikte soru listelerinin (anket formlarına verilen yanıtların) iç tutarlılı̆̆1 ve güvenilirliğini ölçmek için Alfa (Alpha) katsayısı değerine bakılmıştır.

Tablo 1. Güvenilirlik Analizฺ Değerleri

\begin{tabular}{lcc}
\hline & Cronbach's Alfa & Örneklem Sayısı \\
\hline Öz Yeterlilik Algısı &, 879 & 470 \\
Girişimcilik Eğilimleri &, 827 & 470 \\
Yaşam Tatmini &, 846 & 470 \\
\hline
\end{tabular}

Araştırmada kullanılan Öz Yeterlilik Algısı Ölçeğinin güvenilirlik katsayısı (Cronbach’s Alpha) 0,879 olarak belirlenmiştir. Girişimcilik Eğilimleri Ölçeğine ait güvenilirlik katsayısı (Cronbach's Alpha) 0,827 olarak belirlenmiştir. Yaşam Tatmini Ölçeğine ait güvenilirlik katsayısı (Cronbach's Alpha) 0,846 olarak belirlenmiştir.

Alpha katsayısı 0 ile 1 arasında değişen değerler almaktadır. Bu değer 1'e yaklaştıkça ölçek güvenilirliği artmaktadır. Güvenilirliği ölçmek adına hesaplanan Alpha katsayısı 0,40-0.60 arasında bir değer alıyorsa ölçek "düşük güvenilir"; bu katsayı 0,60-0,80 arasında bir değer alıyorsa ölçek "oldukça güvenilir"; 0,801,00 arasında bir değer alıyorsa "yüksek güvenilir" şeklinde ifade edilmiştir (Gürbüz ve Şahin, 2016: 162). Araştırmanın güvenilirlik analizi sonuçları yüksektir.

Tablo 2. KMO ve Bartlett's Tablosu

\begin{tabular}{lc}
\hline KMO Değeri &, 874 \\
Ki Kare Değeri & 4171,984 \\
Sig. &, 000 \\
\hline
\end{tabular}

KMO ve Bartlett's testi sonucuna göre KMO değerinin 0,874 olması, örneklemin faktör analizi için yeterli olduğuna işaret etmektedir ( 0,60 'dan büyük). Sig. değerinin, 000 olması $(p<0,05)$ değişkenler arası ilişkilerin oluşturduğu matrisin faktör analizi için anlamlı olduğunu ve faktör analizi yapılabileceğini göstermektedir (Gürbüz ve Şahin, 2017, s. 325). 
Tablo 3. Faktör Analiæi Sonuclar

\begin{tabular}{|c|c|c|c|}
\hline Madde & $\ddot{O}_{z}$ Yeterlilik Algısı (öya) & Girişimcilik Ĕ̈gilimleri (ge) & Yaşam Tatmini $(y t)$ \\
\hline Öya4 & ,743 & & \\
\hline Öya5 &, 736 & & \\
\hline Öya3 & ,720 & & \\
\hline Öya8 &, 717 & & \\
\hline Öya9 & ,712 & & \\
\hline Öya2 & ,698 & & \\
\hline Öya7 & ,689 & & \\
\hline Öya1 & ,688 & & \\
\hline Öya10 &, 557 & & \\
\hline Öya6 & ,489 & & \\
\hline Ge1 & &, 782 & \\
\hline Ge6 & & ,734 & \\
\hline Ge2 & & ,730 & \\
\hline Ge3 & & ,729 & \\
\hline Ge8 & & ,617 & \\
\hline Ge5 & & ,616 & \\
\hline Ge7 & & ,418 & \\
\hline Ge4 & & ,416 & \\
\hline Yt3 & & & 815 \\
\hline Yt2 & & & ,799 \\
\hline Yt4 & & & ,798 \\
\hline Yt1 & & & ,781 \\
\hline Yt5 & & & ,715 \\
\hline
\end{tabular}

Not: $0,4^{\prime}$ ten küçük faktör yükleri tabloda gösterilmemiştir. Yaşam tatmini, girişimcilik eğilimleri ve öz yeterlilik algisı ölçeklerine uygulanan faktör analizi sonucunda, ölçek ifadelerinin üç faktörde toplandığı görülmüştür. Üç faktör toplam varyansın \%54’ünü açılamaktadır.

\section{Bulgular}

\section{Demografik Bulgular}

Tablo 4'teki sonuçlar incelendiğinde; katıllımcıların \%47'sinin kadın, \%53'ünün erkek olduğu, katılımcıların çoğunluğunun 18-24 yaş arası bireylerden oluştuğu $(\% 34,7)$ tespit edilmiştir. Ayrıca eğitim durumlarının 288 kişi ile lisans mezunu ağırlıklı olduğu (\%61,3) ve medeni durumlarının da 271 çoğunluk ile bekâr $(\% 57,7)$ olduğu görülmüştür.

Tablo 4. Demografik Veriler

\begin{tabular}{|c|c|c|c|}
\hline Değişken & Düzey & $\mathbf{N}$ & $\%$ \\
\hline \multirow{2}{*}{ Cinsiyet } & Kadin & 221 & 47,0 \\
\hline & Erkek & 249 & 53,0 \\
\hline \multirow{5}{*}{ Yaş } & $18-24$ & 163 & 34,7 \\
\hline & $25-31$ & 83 & 17,6 \\
\hline & $32-38$ & 83 & 17,7 \\
\hline & $39-45$ & 71 & 15,1 \\
\hline & 46 ve üstü & 70 & 14,9 \\
\hline \multirow{5}{*}{ Eğitim Durumu } & Orta öğretim & 17 & 3,6 \\
\hline & Lise & 59 & 12,6 \\
\hline & Ön lisans & 65 & 13,8 \\
\hline & Lisans & 288 & 61,3 \\
\hline & Yüksek lisans/Doktora & 41 & 8,7 \\
\hline \multirow{2}{*}{ Medeni Durum } & Evli & 199 & 42,3 \\
\hline & Bekâr & 271 & 57,7 \\
\hline Toplam & & 470 & 100,0 \\
\hline
\end{tabular}


Verilerin normal dağllima uygunluğunun tespiti parametrik veya parametrik olmayan testlerin hangisinin kullanılacağını belirleme noktasında önem arz etmektedir (Gürbüz ve Şahin, 2017, s.230). Bu kapsamda "Öz Yeterlilik Ölçeği”, "Girişimcilik Eğilimleri” ve "Yaşam Tatmini” ölçeği ile ulaşılan verilerin normal dağılıp dağılmadığını tespit etmek için normallik testi uygulanmıştır. Sonuçlar Tablo 6'da gösterilmiştir. Basıklık ve çarpıklık analizlerinin yanısıra normallik testi için ayrıca Kolmogorov Smirnov testi de yapılabilir. Çalışmada Kolmogorov Smirnov testi de yapılmıştır. Test sonucunda bilimsel anlamlılık değeri (p) 0,05’ten küçük çıttı̆ 1 için normal dağılım onaylanmamıştır. Fakat tek ölçüm tekniği Kolmogorov Smirnov değildir. Örneklem sayımız 30’un üzerinde olduğu için merkezi limit teoremine ve basıklık çarpıklık gibi merkezi eğilim ölçülerine göre dağılım normaldir (Gürbüz ve Şahin, 2017, s.240). Bu nedenle normal dağılım analizleri kullanılmıstır.

Tablo 5. Basıklık ve Carpıklık Değerleri

\begin{tabular}{lcc}
\hline & Basıkllk & Carpıklık \\
\hline Öz Yeterlilik Algısı & $-1,056$ & 1,486 \\
Girişimcilik Eğilimleri & -686 &,- 027 \\
Yaşam Tatmini &, 006 &,- 873 \\
\hline
\end{tabular}

Tablo 5’te görüldüğü gibi her iki ölçek verileri için Çarpıklık (Skewness) ve Basıklık (Kurtosis) +1,5 ile 1,5 arasında bir değer aldığı ve normal dağılım gösterdiği tespit edilmiştir. Buna göre değisskenler arasında parametrik testlerin uygulanabileceği görülmüştür.

\section{Hipotez testlerine ilişkin bulgular}

Araşıırmanın gerçekleştirildiği kurumda çalışanların öz yeterlilik algıları, girişimcilik eğilimleri ve yaşam tatminleri arasındaki ilişkiler çoklu korelasyon analizi ile araştırılmıstır.

Tablo 6. Korelasyon Analizi Değerleri

\begin{tabular}{lccc}
\hline Değişkenler & $\ddot{O ̈}_{z}$ Yeterlilik Alg1sı & Girişimcilik Ĕ̈ilimleri & Yaşam Tatmini \\
\hline Öz Yeterlilik Algısı & 1 & & \\
Girişimcilik Eğilimleri &, $433^{* *}$ & 1 & 1 \\
Yaşam Tatmini &, $142^{* *}$ & .162 & 162 \\
\hline
\end{tabular}

$\mathrm{N}: 470, \mathrm{p}^{*}<0.05, \mathrm{p}^{* *<0} 0.01$

Yapılan çoklu korelasyon analizi neticesine göre öz yeterlilik algısı ile girişimcilik eğilimleri arasında pozitif yönlü anlamlı bir ilişki $\left(\mathrm{r}_{(470)}\right.$ : $\left.0,433, \mathrm{p}<0.05\right)$ olduğu görülmüştür. Öz yeterlilik algisı ile yaşam tatmini arasında pozitif yönlü anlamlı bir ilişki $\left(\mathrm{r}_{(470)}: 0,142, \mathrm{p}<0.05\right)$ olduğu tespit edilmiştir. Girişimcilik eğilimleri ile yaşam tatmini arasında anlamlı bir ilişki bulunamamıştır $\left(\mathrm{r}_{(470)}\right.$ : $\left.-0,065, \mathrm{p}>0.05\right)$.

Tablo 7. Regresyon Analizi Değerleri

\begin{tabular}{|c|c|c|c|c|c|c|c|}
\hline $\begin{array}{l}\text { Bağımlı Değişken } \\
\text { Girişimcilike Eğilimleri }\end{array}$ & $B$ & $\begin{array}{c}\text { Standart } \\
\text { Hata }\end{array}$ & $\beta$ & $t$ & $p$ & Tolerans & $V I F$ \\
\hline $\begin{array}{l}\text { (Sabit) } \\
\text { 1. Öz yeterlilik algisı } \\
\text { 2. Yasam tatmini }\end{array}$ & $\begin{array}{l}, 487 \\
-, 102\end{array}$ & $\begin{array}{l}, 045 \\
.033\end{array}$ & $\begin{array}{l}, 452 \\
-, 129\end{array}$ & $\begin{array}{l}10,829 \\
-3,087\end{array}$ & $\begin{array}{l}, 000 \\
, 002\end{array}$ & $\begin{array}{l}, 980 \\
980\end{array}$ & $\begin{array}{l}1,021 \\
1,021\end{array}$ \\
\hline Düzeltilmiş $\mathrm{R}^{2}=, 201 ; \mathrm{R}^{2}=, 204$ & & & $\begin{array}{l}59,857, \\
\text { lova }(\mathrm{A}\end{array}$ & $\begin{array}{l}\text { i Std. H } \\
=, 000\end{array}$ & 62974 & & \\
\hline
\end{tabular}

Tablo 7'deki regresyon analizi sonucu incelendiğinde modelin tamamı için hesaplanmış p değerinin $(, 000) \mathrm{p}<0,05$ anlamllık düzeyinde olduğu görülmektedir. Yapılan analizlerin neticesine göre öz yeterlilik algısının girişimcilik eğilimleri üzerinde pozitif yönlü ve anlamlı bir etkisinin olduğu tespit edilmiştir ( $\beta=$ ,452 $\mathrm{p}<0,001)$. Ayrıca yaşam tatmininin girişimcilik eğilimlerinin yaşam tatmini üzerinde negatif ve anlamlı bir etkisinin olduğu tespit edilmiştir $\mathrm{Bu}$ sonuçlara göre $\mathrm{H}_{1}$ ve $\mathrm{H}_{2}$ hipotezleri kabul edilmiştir. $(\beta=-, 102$ $\mathrm{p}<0,001)$. Tablodaki $\mathrm{R}^{2}$ değeri $(, 204)$ bağımlı değişkendeki (girişimcilik eğilimleri) değişimlerin ne kadarının bağımsız değişkenler (öz yeterlilik algısı, yaşam tatmini) tarafından açıklandığını göstermektedir. Buna göre girişimcilik eğilimlerindeki \%20 'lik varyansın bağımsız değişkenlere bağlı olduğu söylenebilir. Tolerance değeri kritik değerden $\left(1-\mathrm{R}^{2}\right)$ büyük olduğu için çoklu eş doğrusallık problemi bulunmamaktadır $\left(1-\mathrm{R}^{2}=\right.$ ,796 / ,980>,796). 


\section{Tartışma, Sonuç ve Öneriler}

Araştırmanın analizleri incelendiğinde öz yeterlilik algısının girişimcilik eğilimleri üzerinde pozitif yönlü ve anlamlı bir etkisinin olduğu tespit edilmiştir $(\beta=, 452 \mathrm{p}<0.001)$. Bu sonuç Krueger ve Brazeal (1994) tarafından yapılan çalışmanın sonuçları ile uyumlu olup, iki değişken arasındaki nedensellik ilişkisini onaylamaktadır. Ayrıca yaşam tatmininin girişimcilik eğilimleri üzerinde negatif yönlü ve anlamlı bir etkisinin olduğu tespit edilmiştir $(\beta=-, 102 \mathrm{p}<0.001)$. Elde edilen bu sonuç Uçkun vd. (2019) tarafindan yapılan çalışmanın sonucu ile benzer netice göstermektedir. Elde edilen sonucun farklı olmasının nedeni örneklemlerin farklı olmasından kaynaklanmaktadır. Uçkun (2019) çalışmasında örneklem üniversite öğrencileri iken bu çalışmanın örneklemi kamu iktisadi teşebbüsü çalışanlarıdır. Yaşam tatmininin girişimcilik eğilimleri üzerindeki etkisini tespit etmek için yaptığımız analizlerde beta katsayısının $(-0,129)$ negatif olduğu görülmektedir. $\mathrm{Bu}$ durum bireylerin yaşam tatmini düzeyleri arttıkça girişimcilik eğilimlerinde azalma gerçekleşebileceğini işaret etmektedir. Öz yeterlilik algısı yüksek olan kişiler açısından farklı durum ortaya çıkabilecektir. Öz yeterlilik algısı düşük olan kişilerde yaşam tatmininin girişimcilik eğilimleri üzerindeki negatif etkisi artarken, yüksek olan bireylerde ise düşecektir. Her türlü zorluk karşısında pes etmeyen, çözüm yolları üretebilen, güçlükler karşısında soğukkanlı durabilen bireyler girişimciliğin doğasında bulunan bu hususların üstesinden gelmekte daha aktif olmaktadır.

Yaşam tatminini sağlayan her birey girişimcilik konusunda meraklı olmamaktadır. Bunun sebebi de hayattan istediği herşeyi elde etmiş, doyuma ulaşmış olmanın verdiği rahatlıkla yeni bir iş kurmayı, yeni atılımlar yapmayı gereksiz görmesidir. Ancak bu bireylerin içinde öz yeterlilik alg1sı yüksek olanlarda girişimcilik eğilimi oluşabilecektir. Bu sebeple yöneticilere çalışanlarının öz yeterlilik algılarını yükseltmeleri yönünde tavsiye verilebilir. Sosyal bilişsel kuramcılar, kişilerin öz yeterlilik algılarının bir işi yaparken gösterdikleri gayret, o anda duydukları endişe ile belirlendiğini ortaya koymuşlardır. Bu kişiler kendilerinde mevcut performanslarını göstermek için her türlü etkinliği oluşturabilirler ve yerine getirebilirler (Seferoğlu, 2005, s. 93).

Kişilerin öz yeterlilik inançlarını sağlayabilmek için rol model olarak gördüklerinin performanslarını göz önüne almaları önemlidir. Bu kişiler için kendi öz yeterlilik düzeyleri ile ilgili bilgi diğer kişileri gözlemlemekten, başka bireyleri ikna edebilme kabiliyetlerinden vb. elde edilir. Öz yeterlilik algısı örgütsel süreçler üzerinde olan etkisini, bireylerin harekete geçip geçmeme kararlarını ve zorluklar karşısında mücadele yeteneklerini yönlendirerek göstermektedir (Bandura, 1997, s. 196). Araştırmamızın bulgularına göre öz yeterlilik algısının girişimcilik eğilimleri üzerindeki etkisi yaşam tatmininin etkisinden daha yüksektir. Bu sonuç göstermektedir ki çalışanların girişimcilik eğilimlerini arttırmak için öncelikli olarak öz yeterlilik algılarının yükseltilmesine önem verilmelidir. Çalışanların öz yeterlilik algılarını geliştirmek için yöneticilere, eğitim faaliyetleri, çalışanlar açısından olumlu geribildirim, çalışanlarının isteklerini kesin bir şekilde anlayabilmeleri, çalışanların performanslarına ödül, ceza gibi yollarla dönüşlerin sağlanabilmesi vb. yönünde tavsiyeler verilebilir.

$\mathrm{Bu}$ çalışma sadece Ankara merkezli bir kamu iktisadi teşebbüsünün Bandırma şubesinde gerçekleştirilmiştir. Farklı il veya bölgelerde, daha geniş örneklem çerçevesinde benzer çalışmaların yapılması, karşılaştırma açısından olanak sağlayacaktır. Bu çalışma sadece bir kamu iktisadi teşebbüsündeki çalışanlar ile gerçekleştirilmiştir. Farklı meslek gruplarında benzer çalışmalara yer verilmesi literatüre katkı sağlanması açısından önem taşımaktadır.

\section{Etik Beyan}

"Calssanlarn Yaşam Tatmini ve Öz Yeterlilik. Algısınn Girişimcilike Eğilimlerine Etkisis" başlıklı çalışmanın yazım sürecinde bilimsel kurallara, etik ve alıntı kurallarına uyulmuş; toplanan veriler üzerinde herhangi bir tahrifat yapılmamış ve bu çalışma herhangi başka bir akademik yayın ortamına değerlendirme için gönderilmemiştir. Gerekli olan etik kurul izinleri Bandırma Onyedi Eylül Üniversitesi Sosyal ve Beşeri Bilimler Etik Kurulu'nun 18.06.2020 tarih ve 2020-3 sayılı toplantısında alınmıştır.

\section{Kaynakça}

Akgündüz, Y. (2013). Konaklama işletmelerinde iş doyumu, yaşam doyumu ve öz yeterlilik arasındaki ilişkinin analizi. Celal Bayar Üniversitesi Sosyal Bilimler Dergisi, 11(1), 180-204.

Armağan, E. ve Gürsoy, Ö. (2017). Öz yeterlilik algısı ile sosyal girişimcilik eğilimi ilişkisi: işletme öğrencileri üzerinde bir araştırma. 3. Uluslararası Girişimcilike, İstihdam ve Kariyer Kongresi, Muğla.

Arseven, A. (2016). Öz yeterlilik: bir kavram analizi. Literature and History of Turkish or Turkic, 11(19), 63-80. 
Arslan, K. (2002). Üniversiteli gençlerde mesleki tercihler ve girişimcilik eğilimleri. Doğuş Üniversitesi Dergisi, 2(3), 1-11.

Aşan, Ö. ve Erenler, E. (2008). İş tatmini ve yaşam tatmini ilişkisi. Süleyman Demirel Üniversitesi İktisadi ve İdari Bilimler Fakilltesi Dergisi, 13(2), 203-216.

Aşkar, P. ve Umay, A. (2001). İlköğretim matematik öğretmenliği öğrencilerinin bilgisayarla ilgili öz yeterlilik algisı. Hacettepe Üniversitesi Eğitim Fakïltesi Dergisi, 1(21), 1-8.

Bandura, A. (1997). Self-efficacy: Toward a unifying theory of behavioral change. Psychological Review, 84(2), 191-215.

Bir, Y. (2017). İs ve yașam tatmini arasindaki iliškiye etki eden demografik değisskenler. Bir uluslararası firma uygulaması (Yüksek Lisans Tezi). Çă̆ Üniversitesi Sosyal Bilimleri Enstitüsü, Mersin.

Bockorny, K. ve Youssef-Morgan, C. M. (2019). Entrepreneurs' courage, psychological capital and life satisfaction. Frontiers in Psychology, 10, 1-6.

Bong, M. ve Skaalvik, E. M. (2003). Academic self concept and self efficacy: How different are they really. Educational Psychology Review, 15(1), 5-14.

Ceyhan, S., Y1ltay, S. ve Batga, B. (2020). Duygusal zeka ile girişimcilik eğilimi arasında öz yeterliliğin aracillk rolü: Çukurova Üniversitesi'nde bir araştırma. International Journal Entrepreneurship and Management Inquiries , 4(6), 9-19.

Çetin, F. (2011). Örgüt içi girişimcilik öz yeterlilik algııı ve kontrol odağının rolü. Business and Economics Research Journal, 2(3), 69-85.

Dejonge, T., Veenhoven, R., Kalminjn, W. ve Arends, L. (2016). Pooling time seriesbased on slightly different questions about the same topic forty years of survey research on happinessand life satisfaction in the Netherlands. SocIndicRes., 1(126), 863-891.

Demir, F., Yıldız, A. ve Fırat, A. (2020). Kamuda istihdam istek ve baskısının girişimcilik eğilimi üzerine etkisinin belirlenmesi: Kalitatif bir analiz. Girișimcilik. Inovasyon ve Pazarlama Arastırmalar Dergisi , 4(7), 25-40.

Diener, E., Emmons, R., Larsen, R. ve Griffin, S. (1985). The satisfaction with life scale. Journal of Personality Assessment, 49, 71-75.

Ersoy, H. (2010). Kültürel çevrenin girişimcilik tercihine etkisi. Organizasyon ve Yönetim Bilimleri Dergisi, 1(2), 71-77.

Friedman, I. A. (2003). Self efficacy and burnout in teaching: The importance of enterpersonal-relations efficacy. Social Psychology of Education, 6(5), 91-215.

Gök, F. (2020). Üniversite öğrencilerinin yaşam tatminini yordayan değişkenlerin incelenmesi. Uluslararası Sosyal Araşstrmalar Dergisi , 13(70), 867-873.

Gürbüz, S. ve Şahin, F. (2017). Sosyal bilimlerde araştırma yöntemleri, felsefe-yöntem analiz. Ankara: Seçkin Yayınclik.

Güreşçi, E. (2014). Girişimcilik eğilimi üzerine bir araştırma: İspir Hamza Polat MYO örneği. Girişimcilike ve Kalkımma Dergisi, 1(9), 23-38.

Haybron, D. (2007). Life satisfaction ethical reflection and the science of happiness. Journal of Happiness Studies, 4(34), 99-138.

İşcan, Ö. F. ve Kaygın, F. (2011). Potansiyel girişimciler olarak üniversite öğrencilerinin girişimcilik eğilimlerini belirlemeye yönelik bir araştırma. Organizasyon Ev Yönetim Bilimleri Dergisi, 3(2), 275-286.

Kaya, Ö. (2006). Askeri ögrencilerin yaşam doyumlar üzerine bir araştrma (Yüksek Lisans Tezi). Gazi Üniversitesi, Eğitim Bilimleri Enstitüsü Ankara.

Kotaman, H. (2008). Öz yeterlilik inancı ve öğrenme performansının geliştirilmesine ilişkin yazın taraması. Eğitim Fakïltesi Dergisi, 19(1), 111-133.

Krueger, N. F. ve Brazeal, D. V. (1994). Entrepreneurial potential and potential entrepreneurs. Entrepreneurship Theory and Practice, 18, 91-104.

Kulualp, H. ve Sarı, Ö. (2019). Tüketici davranışına göre müşteri sadakat programı algısının ilişkisel pazarlama kapsaminda incelenmesi. IBAD Sosyal Bilimler Dergisi, 5, 48-69.

Luszczynska, A., Gutierrez- Dona, B. ve Schwarzer, R. (2005). General self-efficacy in various domains of human functioning: Evidence from five countries. International Journal of Psychology, 40(2), 80-89.

Morris, M. H., Vuuren, J., Cornwall, J. R. ve Scheepers, R. (2009). Properties of balance: A pendulum effect in corporate entrepreneurship. Business Horizons, 52, 429-440.

Nobre, G. (2019). Self efficacy profile in daily activities: Children at risk and with development coordination disorder. Pediatrics \& Neonatology, 47(6), 2-12.

Nybakk, E. ve Hansen, E. (2008). Entrepreneurial attitude, innovation and performance among Norwegian naturebased tourism enterprises. Forest Policy And Economics, 10, 473-479.

Oğuzhan, Y. S. (2020). Çalışanların öz yeterlilik algısının örgütsel sinizm ve örgütsel güvene etkisi üzerine bir araştırma. Erciyes Üniversitesi Sosyal Bilimler Enstitiisü Dergisi , 1, 433-449.

Özdevecioğlu, M. ve Aktaş, A. (2007). Kariyer bağlllğ̆1, mesleki bağlllık ve örgütsel bağllliğın yaşam tatmini üzerindeki etkisi: İş-aile çatışmasının rolü. Eriiyes Üniversitesi İktisadi ve İdari Bilimler Fakülttesi Dergisi, 1(28), 1-20.

Özer, M. ve Karabulut, Ö. (2003). Yaşlllarda yaşam doyumu. Turkish Journal of Geriatrics, 2(6), 72-74.

Özerkan, E. (2007). Ögrretmenlerin ö yeterlilik algzlar ile ögrencilerin sosyal bilgiler benlik kavramlar arasindaki iliski (Yüksek Lisans Tezi). Trakya Üniversitesi Sosyal Bilimleri Enstitüsü, Edirne.

Özgül, E. ve Yücel, E. (2018). Girişimcilik merakı ile yenilikçilik arasındaki ilişkide girişimcilik öz-yeterliliğinin aracılık rolü. Yönetim Bilimleri Dergisi, 16(31), 331-353.

Prihatsanti, U. (2017). The relationship between entrepreneurial self-efficacy, entrepreneurial curiosity and innovative behavior on entrepreneur students. Advances in Social Science, Education and Humanities Research, 133, 131-134. 
Schwarzer, R., Muller, J. ve Greenglass, E. (1999). Assessment of perceived general self-efficacy on the internet: Data collection in cyberspace. Anxiety Stress \& Coping, 12(2), 145-161.

Seçgin, Y. (2020). Girişimcilik eğitiminin girişimcilik eğilimi üzerine etkisi: Üniversite öğrencileri üzerine bir araştırma. Business and Management Studies: An International Journal, 8(1), 803-827.

Seferoğlu, S. S. ve Akbıyık, C. (2005). İlköğretim öğretmenlerinin bilgisayara yönelik öz-yeterlik algıları üzerine bir çalışma. Ë̆itim Araştırmaları, 30(30), 89-101.

Shane, S. ve Venkataraman, S. (2000). The promise of entrepreneurship as A field of research. Academy of Management Review, 1(25), 217-226.

Sherer, M. ve Maddux, J. E. (1982). The self efficacy scale: Construction and validation. Psychological Reports, 51(1), 663-668.

Sözbilir, F. (2018). İşbaşı eğitim uygulamaları, öz yeterlilik ve yenilikçilik davranışı arasındaki ilişki. Journal of Business Research Turk, 10(1), 121-133.

Tajeddini, K. (2010). Effect of customer orientation and entrepreneurial orientation on innovativeness: Evidence from the hotel industry in Switzerland. Tourism Management, 31, 221-231.

Tuncer, M. ve Tanaş, R. (2011). Eğitim fakültesi öğrencilerinin bilgisayar öz yeterlilik algılarının değerlendirilmesi. Adiyaman Üniversitesi Sosyal Bilimler Enstitüsü Dergisi, 4(6), 222-230.

Uçkun, C., Korkmaz, F. ve Yener, S. (2019). Öz-yönelimin yaşam tatmini üzerindeki etkisinde girişimcilik algısının arac1 rolü. Uluslararası Sosyal ve Eğitim Bilimleri Dergisi, 12(6), 148-166.

Urgan, S. (2020). Gönüllü hizmetlerde vicdanî zekânın yaşam tatmini ve iş performansına etkisi: Eskişehir Akut örneği. Business and Management Studies: An International Journal, 3(8), 2727-2749.

Yağar, F., Dökme, S. ve Coşkun, S. (2020). Öz yeterlik düzeyinin ve demografik faktörlerin girişimcilik eğilimi üzerindeki etkisi: Üniversite öğrencileri üzerine bir çalışma. Süleyman Demirel Üniversitesi Sosyal Bilimler Enstitüsü Dergisi, 2(37), 302-314.

Yılmaz, E. ve Sünbül, A. M. (2011). Üniversite öğrencilerine yönelik girişimcilik ölçeği. Selçuk Üniversitesi Sosyal Bilimler Enstitïsü Dergisi, 21, 195-203.

Yorganc1, A. E. ve Bozgeyikli, H. (2016). Sınıf öğretmenlerinin kişilerarası öz yeterlilik algılarıyla örgütsel güven algılarının incelenmesi. OPUS Uluslararası Toplum Araștırmalar Dergisi, 6(10), 48-60.

Yöney, E. ve Kılınç, E. (2020). Bankacılık sektöründe psikolojik yıldırmanın çalışanların İş ve yaşam tatmini üzerindeki etkisinin incelenmesi. İktisadi İdari ve Siyasal Arastormalar Dergisi, 5(11), 34-52.

Zimmermann, B. J. (2000). Self Efficacy: An essential motive to learn. Contemporary Educational Psychology, 25 , 82-91.

\section{EXTENDED ABSTRACT}

The aim of this study is to determine the effect of life satisfaction and self-efficacy perception variables on entrepreneurship tendencies, to make a conceptual literature review, to make definitions of these concepts and to examine their differences from other concepts. The concept of self-efficacy, which reveals the belief that people can do a certain job, has a motivating effect on people to make more effort than necessary to achieve that job (Kotaman, 2008, p. 125). According to this concept, the person has confidence that he / she will do certain tasks as expected. Employees have the belief that they can cope with difficult situations themselves with their lifelong experiences, and as their self-efficacy beliefs increase, their behavior changes also occur. For this reason, the perception of self-efficacy has become a phenomenon encountered everywhere where individuals' individual development is a concern (Çetin, 2011, p. 85). The concept of entrepreneurship, which constitutes the basic dynamics of economic developments, has attracted attention and entered the literature because it increases individual and social welfare. Entrepreneurial tendency is related to the individual's desire to become an entrepreneur and therefore to trust himself. Although it is not known whether the concept of entrepreneurial tendency is acquired or congenital, it should be revealed, developed and directed as a behavior (Seçgin, 2020, p. 815). Life satisfaction, which expresses the satisfaction of individuals with life, is defined as an emotionally based process in which they evaluate their own quality of life.

The life satisfaction of individuals will increase as the harmony between the things they obtain from life and their expectations occurs. The state of positive affect resulting from the harmony between expectations and what life brings is called life satisfaction. Although life satisfaction is one of the most important factors of quality of life, it also explains how well the mental and physical health of individuals develops (Dejonge et al., 2016, p. 881). Considering the factors described above, it is predicted that selfefficacy perception has a positive and significant effect on entrepreneurship tendencies, and life satisfaction has a negative and significant effect on entrepreneurship tendencies. Determining the strength and direction of this effect or relationship is the problem of the study. Domestic and foreign literature was examined in order to determine whether there is any study that deals with the relationship between the variables of life satisfaction, self-efficacy perception and entrepreneurial tendencies, but no study in which 
three variables were found together. The main question of the research is whether life satisfaction has an effect on the increase of entrepreneurial tendencies in individuals and what is the role of self-efficacy perception related to this effect. It is thought that this study will make significant contributions to the literature since it is the first study to address the relationship between self-efficacy perception, life satisfaction and entrepreneurial tendencies.

A state economic enterprise with branches in Bandirma and Ankara was chosen for the research. In order to carry out the survey study in this institution, "Ethics Committee Approval" was obtained from the ethics committee of Bandırma Onyedi Eylül University, meeting number 2020/3 and dated 18.06.2020. The universe of the research consists of 650 employees working in the state economic enterprise located in Bandırma and Ankara, and the sample is 470 employees. According to the results, the entrepreneurial desire of the employees with high self-efficacy perception and the positive contribution of self-efficacy to entrepreneurial tendency is one of the results of this study. Individuals who do not give up in the face of all kinds of difficulties, who can produce solutions and those who can stand calmly against difficulties are more active in overcoming these issues inherent in entrepreneurship. Not every individual who provides life satisfaction is curious about entrepreneurship. The reason for this is that he sees it unnecessary to start a new business and make new breakthroughs with the comfort of having everything he wants from life and attaining satisfaction. However, among these individuals, those with high selfefficacy perception will be interested in entrepreneurship. For this reason, managers may be advised to increase their employees' self-efficacy perceptions. Social cognitive theorists have revealed that people's self-efficacy perceptions are determined by the effort they show while doing a job and the anxiety they feel at that moment. These people can create and fulfill all kinds of activities to show their current performances (Seferoğlu, 2005, p. 93). It is important for people to consider the performance of those they see as role models in order to ensure their self-efficacy beliefs. In order to improve the self-efficacy perceptions of the employees, it is aimed to provide managers with training activities, positive feedback for employees, understanding the demands of their employees precisely, providing employees' performance with rewards and punishments. Recommendations can be given. 